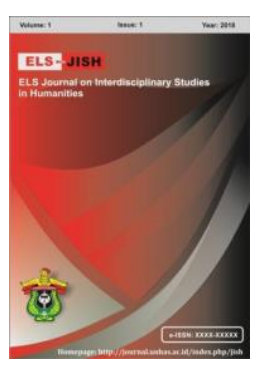

ELS-JISH

ELS Journal on Interdisciplinary Studies on Humanities

Volume 3 Issue 4, 2020

ISSN (print) : 2621-0843

ISSN (online) : 2621-0835

Homepage : http://journal.unhas.ac.id/index.php/jish

\title{
EFL Learners of Pre-Service Teacher Programs' Knowledge of Collocation and Their Perceptions on Collocation
}

\author{
Darmawan ${ }^{1 *}$, Yohanes San Salvador L. Gili ${ }^{2}$, Felisitas Siano ${ }^{3}$ \\ 1 wawanlabira@gmail.com
}

\begin{abstract}
This paper was aimed to find out: (1) EFL learners of pre-service teaching program's knowledge of collocation, and (2) EFL learners of pre-service teaching program's perception about their knowledge of collocation and on collocation teaching in EFL setting. The data was collected from EFL learners of pre-service teaching programs of IKIP Muhammadiyah Maumere in Maumere East Nusa tenggara, Indonesia. To collect the data, a multiple choice of collocation test that consisted of thirty items was administered and 9 item of questionnaires about their perception toward collocation teaching materials, collocation learning methods, and collocation teaching techniques. The findings revealed that the average percentage of EFL learners of preservice teaching program's collocation errors through statistical analysis using SPSS 25.0 was $51,50 \%$ (an average of 4.85 errors per participants). It was identified that $56.30 \%$ grammatical errors (an average of 10.68 errors per participants) and $42.60 \%$ lexical errors (an average of 10.54 errors per essay) were found. This implies that the most frequently committed errors were in the grammatical category. The study also revealed that $80 \%$ of EFL learners of pre-service teaching program agreed that the role of collocation in teaching and learning vocabulary was very important. $43 \%$ of them mostly learn collocations from the course book. They agreed that the most suitable level to learn o $r$ teach collocations are from around elementary. They learn collocation bacause It is important for language proficiency while $30 \%$ of them said that techniques do you use in learning collocations was through translating. $40 \%$ of them agreed that reading was language skill(s) would be the most effective in learning collocations. The causes their collocational errors were $43 \%$ of them agreed that there is interference from Indonesian.
\end{abstract}

Keywords: Collocation errors, grammatical collocation, lexical collocation.

How to cite: Darmawan, Gili, Y \& Siano, F. (2020). EFL Learners of Pre-Service Teacher Programs' Knowledge of Collocation and Their Perceptions on Collocation. ELS-Journal on Interdisciplinary Studies in Humanities, 3(4), 615-628. DOI:

https://doi.org/10.34050/elsjish.v3i4.11951

\section{Introduction}

There has been thematic framework of theoretical and empirical investigations on collocation issues and practices toward EFL learners' receptive and productive skills reflecting the continuing problem in a research field. EFL learners' receptive and productive skills toward collocations have been measured by means of collocation tests. The global spread of corpus analysis based on EFL learners' written work has been used to explore EFL

${ }^{123}$ IKIP Muhammadiyah Maumereer, Indonesia 
learners' knowledge of collocations. (Bahardouzt \& Moeini 2012; Torabian, Maros \& Subakir 2014; Yazdandoost, Saleh \& Kafipour 2014; Fadlilah 2016; Mutlu \& Kaşlioğlu 2016; Owu-Ewie \& Williams 2017). EFL learners' knowledge of collocations based on EFL learners' speaking skills has been investigated in several studies. (Farrokh 2012; Shamsudin, Sadoughvanini \& Zaid 2013; Fanaee 2014; Yazdandoost, Saleh \& Kafipour 2014; Alsulayyi 2015; Qader 2018). In the field of translation, some studies have been conducted in relation with EFL learners' knowledge of collocations. (Dweik \& Mariam \& Abu Shakra 2011; Al-Sofi, Maros and Baker 2014; Malenica \& Mustapić 2015).

The variety of approaches in the range of theoretical positions and the research practices brought the perspectives that collocations are still controversial issues for language EFL learners'. Based on analyses of EFL learners' receptive and productive knowledge of collocations, researchers have identified that most collocation errors stem from first language interference, and that mastering collocations is a challenging task even for advanced level learners. Surprisingly, receptive knowledge of the EFL learners on collocations was higher than their productive knowledge, and vocabulary size positively correlated with collocation knowledge.

It is undeniable proof that vocabulary is one of the language areas which have been considered prominently and has been paid by different teaching approaches for decades in second and/or language teaching and learning is (Rahman, 2018). Therefore, the center of language teaching and learning should've been vocabulary, instead of grammar. Furthermore, choosing adequate words is considered more important than choosing adequate grammar structure in some certain situations. Molavi ( 2014, p 60) stated that the key element to achieve a high level of language learning proficiency is by earned vocabulary. He also believed that one of the communicative competences is vocabulary knowledge and should be considered learning vocabulary as an integral part of second and/or language learning.

Alsullayi (2015) pointed out that "in vocabulary teaching there is a high importance of collocation, the relationship of collocation is fundamental in the study of vocabulary, and collocation is an important organising principle in the vocabulary of any language". Vocabulary teaching and learning is habitually focused on the concepts of individual word and its usage. EFL learners' knowledge of collocations is developed along with their vocabulary, at the same time. However, the problem of collocation and in fact word combinations deserves even more attention than the amount it has received so far. Ahangari, S., \& Zununi V (2013) maintain that, "one of the main difficulties students encounter in relation to new items of vocabulary is what their collocation properties are".

According to the Oxford Collocations Dictionary (2002), collocation is a way of combining words within a language in order to produce natural-sounding speaking and writing. Ni Luh Putu Setiarini (2018) referred to collocation is combination of word and formulaic language as one entity. Alsulayyi (2014) categorized collocation into grammatical collocation and lexical collocation. Lexical collocation is made up of content words which are constructed of verb, noun, adverb, and adjective. There are seven types of lexical collocations, they 
are: Verb (activation, donating, or creation) + noun (prepositional phrase or pronoun), Verb (meaning nullification or eradication) + noun, Adjective + noun, Noun + verb (action), Noun1 of noun2, adjective + adverb; adverb + adjective, Verb + adverb.

In the other side, grammatical collocation is formed of dominant words, such as adjective, a noun, or a verb, and a preposition or grammatical structure like an infinitive or a clause. There are eight types of grammatical collocations, they are: Noun + preposition, Noun + to infinitive, Noun + that clause, Preposition + noun, Adjective + preposition, Predicate adjective + to infinitive, Adjective + that clause. The basic difference of them is lexical collocation does not contain prepositions, infinitives or clauses; meanwhile, grammatical collocation contains content words together with preposition, infinitives and clauses.

Rao (2018) stated that one of the native speaker's competence is collocation and even at advanced levels EFL learners have various problems with it. Erroneous utterances like 'quick food' and 'speed car' are undeniable proof of a lack of collocation knowledge. It revealed that students' knowledge of collocations is developed with their knowledge of vocabulary, at the same time. Therefore, collocational knowledge is included in EFL learners' knowledge that a language and a native speaker's knowledge contains and awareness of patterns of collocations in the language.

The crucial and significance role of collocations and their relevance to English language earning has triggered a larger scale of studies on the learner's collocation knowledge, revealing the significant role of collocation in EFL learners, and identifying ways to enhance EFL learners' collocation competence. Since researches about this subject are extensive, the researcher stated only some of them. Rao (2018) stated that collocations are highly crucial to EFL learners and highly essential in second language acquisition. Collocations should have been given more extra attention and teaching vocabulary should be considered as a foreign culture, grammatical, lexical and phonological subsystems.

Maryani (2012) on her paper stated that lexical collocation is more difficult than grammatical one faced by the EFL learners. Most of them have been exposed to various types of collocations; however, most of Indonesian collocations and English collocations were highly different in terms of syntax and morphology.

Setiarini (2018) found out that most of translation errors in term of collocations made by the students are lexical errors than grammatical errors. She stated that regarding to techniques of translation; they were generalization, creation, discursive, reduction, compression, literal translation. Furthermore, she said that the cause of those collocation errors is the interference of the native language.

Those studies above confirmed that it still problems for EFL learners. Not many of them are conscious of the existence of collocations. In fact, they give more meaning to grammar and the grammar translation approach plays a key role in the EFL in Indonesia for decades. Additionally, first language 
interference is a considerable problem in English teaching. They have been teaching individual words rather than collocations and eventually they find it difficult in facing collocations. It is believed that the EFL learners which have been exposing to a large number of individual words, are not fully capable in formulating collocations. Obviously, it is highly necessary to have enough knowledge of collocations.

However, studies those investigating knowledge of collocations toward EFL learners of pre-service teaching program are rare in the Indonesian context. So as a language researcher in an EFL environment (Indonesia) has come to the point to investigate knowledge of collocations of EFL learners of pre-service teaching program, including their attitude toward teaching materials, learning methods, and teaching techniques. Researchers believe that it is highly significant as the situations manifest the importance of knowledge of collocations for EFL learners of pre-service teaching program.

\section{Method}

There were 35 EFL learners of pre-service teaching program. Their ages were in between 20-24 and had been learning English for approximately 6 years. Mostly, they used English inside or outside the classroom, such as: chatting with foreigners and watching movies and English news.

In order to elicit their collocation knowledge, researchers used thirty items of multiple choices which were divided into two parts. The first part consisted of 15 items of grammatical collocation and the second part consisted of lexical collocation. The students were unallowed using dictionaries during the test.

The second questionnaires focused on their thought about teaching collocations, techniques and collocation teaching frequencies, opinions on their collocation errors, and suggestions about the techniques in teaching collocations effectively. There were 6 main issues in the questionnaire. Questions $1-3$ were displayed for the first research question and the rests were displayed to highlight the second research question.

The EFL learners of pre-service teaching program test of collocation will be highlighted and analyzed quantitatively. They were simply scored based on the correct or incorrect criteria. The correct answer got one point and incorrect answer zero point. The data were broadly categorized the errors into grammatical collocation and lexical collocation errors. They were analyzed using SPSS. Errors frequencies and converted into percentage and then presented on graphs. Also, errors were classified in order to see most common collocation errors.

\section{Finding}

\subsection{Investigate the collocation ability of EFL learners of pre-service teaching program}

To obtain data about EFL learners of pre-service teaching program knowledge of collocations, a collocational test instrument was administered. Each student's score indicator was calculated by dividing the number of 
student's collocational errors with the number of multiple choice test items then multiply by $100 \%$.

Table 1. Error percentage of students collocation test

\begin{tabular}{|c|c|c|c|}
\hline No & Error (\%) & $\begin{array}{c}\text { Grammatical Collocation } \\
\text { errors (\%) }\end{array}$ & $\begin{array}{l}\text { Lexical Collocation } \\
\text { errors (\%) }\end{array}$ \\
\hline 1 & 53 & 60 & 40 \\
\hline 2 & 43 & 53 & 37 \\
\hline 3 & 43 & 53 & 37 \\
\hline 4 & 53 & 40 & 60 \\
\hline 5 & 63 & 37 & 53 \\
\hline 6 & 40 & 57 & 33 \\
\hline 7 & 53 & 40 & 60 \\
\hline 8 & 40 & 46 & 54 \\
\hline 9 & 53 & 37 & 53 \\
\hline 10 & 56 & 57 & 33 \\
\hline 11 & 46 & 40 & 60 \\
\hline 12 & 53 & 46 & 54 \\
\hline 13 & 40 & 33 & 46 \\
\hline 14 & 46 & 53 & 37 \\
\hline 15 & 53 & 53 & 37 \\
\hline 16 & 50 & 40 & 60 \\
\hline 17 & 53 & 37 & 53 \\
\hline 18 & 40 & 37 & 53 \\
\hline 19 & 40 & 57 & 33 \\
\hline 20 & 53 & 40 & 60 \\
\hline 21 & 50 & 46 & 54 \\
\hline 22 & 56 & 37 & 53 \\
\hline 23 & 56 & 57 & 33 \\
\hline 24 & 40 & 40 & 60 \\
\hline 25 & 53 & 37 & 53 \\
\hline 26 & 36 & 57 & 33 \\
\hline 27 & 56 & 40 & 60 \\
\hline 28 & 46 & 46 & 54 \\
\hline 29 & 50 & 37 & 53 \\
\hline 30 & 56 & 57 & 33 \\
\hline
\end{tabular}

Base on the table above, the highest percentage of student errors in collocation knowledge is $63 \%$ while the lowest errors percentage is $43 \%$. The highest percentage of student grammatical collocation errors is $60 \%$ while the lowest errors percentage is $33 \%$. In the other hand, the highest percentage of student lexical collocation errors is $60 \%$ while the lowest errors percentage is $33 \%$.

Table 2. Collocation errors percentage

\begin{tabular}{ccccc}
\hline & $\mathrm{N}$ & Mean & Std. Deviation & Std. Error Mean \\
\hline EP & 30 & 51.50 & 4.855 & .886 \\
\hline
\end{tabular}


The average percentage of EFL learners of pre-service teaching program collocation errors through statistical analysis using SPSS 25.0 is $51,50 \%$ (an average of 4.85 errors per participants).

This section looks at which grammatical or lexical errors were frequently committed by the EFL learners of pre-service teaching program under discussion. The errors are collected from the data are broadly categorized into grammatical errors and lexical errors.

Table 3 Grammatical collocation errors

\begin{tabular}{|c|c|c|c|}
\hline $\mathrm{N}$ & Mean & $\begin{array}{c}\text { Std. } \\
\text { Deviation }\end{array}$ & $\begin{array}{l}\text { Std. Error } \\
\text { Mean }\end{array}$ \\
\hline GP 30 & 56.30 & 10.681 & 1.950 \\
\hline
\end{tabular}

The average percentage of EFL learners of pre-service teaching program collocation errors through statistical analysis using SPSS 25.0 is $56,30 \%$ (an average of 10.68 errors per participants).

Table 4 Classification of the students' grammatical collocation ability

\begin{tabular}{ccc} 
No & Patterns' Classification & Errors (\%) \\
\hline 1 & Noun + preposition & 30 \\
\hline 2 & Noun + to infinitive & 20 \\
\hline 3 & Noun + that clause & 36 \\
\hline 4 & Preposition + noun & 43 \\
\hline 5 & Adjective + preposition & 20 \\
\hline 6 & Predicate adjective + to infinitive & 36 \\
\hline 7 & Adjective + that clause & 40 \\
\hline
\end{tabular}

Table 5 Lexical collocation errors

\begin{tabular}{ccccc}
\hline & N & Mean & $\begin{array}{c}\text { Std. } \\
\text { Deviation }\end{array}$ & $\begin{array}{c}\text { Std. Error } \\
\text { Mean }\end{array}$ \\
\hline EL & 30 & 42.60 & 10.543 & 1.925 \\
\hline
\end{tabular}

The average percentage of EFL learners of pre-service teaching program collocation errors through statistical analysis using SPSS 25.0 is $42,60 \%$ (an average of 10.54 errors per participants).

Table 6 Classification of the students' lexical collocation ability

\begin{tabular}{clc} 
No & Patterns' Classification & Errors $(\%)$ \\
\hline 1 & Verb + noun & 40 \\
\hline 2 & Verb + noun & 20 \\
\hline 3 & Adjective + noun & 23 \\
\hline 4 & Noun + verb & 33 \\
\hline 5 & Noun1 of noun2 & 23 \\
\hline 6 & adverb + adjective & 43 \\
\hline
\end{tabular}


$7 \quad$ Verb + adverb

23

Based on table 3 about grammatical collocation errors and table 5 about lexical collocation errors show that the most frequently errors made by the EFL learners of pre-service teaching program were grammatical collocation $(56.30 \%)$ than lexical collocation errors were $(42.60 \%)$.

\subsection{EFL learners of pre-service teaching program Questionnaires}

This section looks at EFL learners of pre-service teaching program responses toward questionnaris.

Table 7. The role of collocation in teaching vocabulary

\begin{tabular}{clcc}
\hline \multirow{2}{*}{ Item } & \multicolumn{1}{c}{ Options } & \multicolumn{2}{c}{ Teachers } \\
\cline { 2 - 4 } & & $f$ & $\%$ \\
\hline \multirow{3}{*}{$\begin{array}{l}\text { What is the role of } \\
\text { collocation in teaching } \\
\text { vocabulary? }\end{array}$} & Very important & 24 & $80 \%$ \\
\cline { 2 - 4 } & Important & 4 & $13 \%$ \\
\cline { 2 - 4 } & I am not sure & 2 & $7 \%$ \\
\cline { 2 - 4 } & Not very important & 0 & $0 \%$ \\
\cline { 2 - 4 } & Not important & 0 & $0 \%$ \\
\hline \multicolumn{1}{c}{ Total } & & 30 & $100 \%$ \\
\hline
\end{tabular}

Table 7 shows that 24 out of 30 (80\%) EFL learners of pre-service teaching program believed that the role of collocation in teaching vocabulary is very important while 4 out of 30 (13\%) EFL learners of pre-service teaching program believed that the role of collocation in teaching vocabulary is important and 2 out of $30(7 \%)$ EFL learners of pre-service teaching program were not sure about the role of collocations.

Table 8. Presentation of collocations

\begin{tabular}{cccc}
\hline \multirow{2}{*}{ Item } & \multirow{2}{*}{ Options } & \multicolumn{2}{c}{ Teachers } \\
\cline { 2 - 4 } & & $f$ & $\%$ \\
\hline \multirow{3}{*}{ How often do you learn collocation? } & Always & 12 & $40 \%$ \\
\cline { 2 - 4 } & Mostly & 13 & $43 \%$ \\
\cline { 2 - 4 } & Sometimes & 3 & $10 \%$ \\
\cline { 2 - 4 } & Rarely & 2 & $7 \%$ \\
\cline { 2 - 4 } & Never & 0 & $0 \%$ \\
\hline Total & & 30 & $100 \%$ \\
\hline
\end{tabular}

Based on table 8, 12 out of 30 (40\%) EFL learners of pre-service teaching program stated that they always present collocation in teaching vocabulary while $13(43 \%)$ EFL learners of pre-service teaching program stated that they mostly present collocation and $3(10 \%)$ EFL learners of pre-service teaching program sometimes present them in classes. There were only $2(7 \%) \mathrm{EFL}$ 
learners of pre-service teaching program stated that they rarely present collocation. No teachers stated that they never present collocation.

Table 9. Chose to teach collocation

\begin{tabular}{llccc}
\hline \multirow{2}{*}{ Item } & \multicolumn{1}{c}{ Options } & \multicolumn{2}{c}{ Teachers } \\
\cline { 2 - 4 } & & $f$ & $\%$ \\
\hline Do you learn the whole & & 16 & $53 \%$ \\
\cline { 2 - 4 } $\begin{array}{l}\text { collocations in the course } \\
\text { book or choose to teach the } \\
\text { most used ones? }\end{array}$ & All collocations & Most frequently used collocations & 10 & $33 \%$ \\
\cline { 2 - 5 } \multicolumn{1}{c}{ Total } & I learn words in isolation & 4 & $13 \%$ \\
\hline
\end{tabular}

Table 9 showes that In terms of choosing collocations in teaching vocabularies in course books they used, 16 of 30 (53\%) EFL learners of preservice teaching program answered that they chose to teach all collocations in the course book, while 10 (33\%) EFL learners of pre-service teaching program answered that they choose teaching the most common ones and $4(13 \%) \mathrm{EFL}$ learners of pre-service teaching program answered that they learn words in isolation

Table 10. level to teach collocations

\begin{tabular}{clccc}
\hline \multirow{2}{*}{ Item } & \multirow{2}{*}{ Options } & \multicolumn{2}{c}{ Teachers } \\
\cline { 3 - 4 } & & $f$ & $\%$ \\
\hline \multirow{2}{*}{$\begin{array}{l}\text { Which level is the most suitable to } \\
\text { teach/learn collocations? }\end{array}$} & Around elementary & 13 & $43 \%$ \\
\cline { 2 - 4 } & Around intermediate & 11 & $37 \%$ \\
\cline { 2 - 4 } & At any level & 6 & $20 \%$ \\
\hline Total & 30 & $100 \%$ \\
\hline
\end{tabular}

Table 10 showes in terms of the most suitable level to teach collocations; $13(43 \%)$ EFL learners of pre-service teaching program indicated that it can be taught at any level, while $11(37 \%)$ EFL learners of pre-service teaching program stated that it should be around intermediate, and 6 (20\%) EFL learners of pre-service teaching program believed around elementary.

Table 11. Reasons to each/learn collocations

\begin{tabular}{llrr}
\hline \multirow{2}{*}{ Item } & \multicolumn{1}{c}{ Options } & \multicolumn{2}{c}{ Teachers } \\
\cline { 3 - 5 } & & $f$ & $\%$ \\
\hline \multirow{3}{*}{$\begin{array}{l}\text { Why do you } \\
\text { learn } \\
\text { collocations? }\end{array}$} & It is mandatory in the syllabus listing & 6 & $20 \%$ \\
\cline { 2 - 5 } & It is common in general English & 8 & $27 \%$ \\
\cline { 2 - 5 } & It is important for language proficiency & 7 & $23 \%$ \\
\cline { 2 - 5 } & Students habitually learn individual words & 9 & $30 \%$ \\
\cline { 2 - 5 } & Students poor knowledge on it & 30 & $100 \%$ \\
\hline \multicolumn{1}{c}{ Total } & & & \\
\hline
\end{tabular}

Table 11 showes that the three most common reasons EFL learners of pre-service teaching program provided for teaching collocations were $9(30 \%)$ 
EFL learners of pre-service teaching program habitually learn individual words, $8(27 \%)$ EFL learners of pre-service teaching program stated that commonly in general English, 7 (23\%) EFL learners of pre-service teaching program it is important for language proficiency and 6 (20\%). None of the EFL learners of pre-service teaching program included student's poor knowledge.

Table 12. Techniques for collocation focus

\begin{tabular}{llrr}
\hline \multirow{2}{*}{ Item } & \multicolumn{1}{c}{ Options } & \multicolumn{2}{c}{ Teachers } \\
\cline { 2 - 4 } & & $f$ & $\%$ \\
\hline \multirow{3}{*}{$\begin{array}{l}\text { Which techniques do you } \\
\text { use in learning } \\
\text { collocations? }\end{array}$} & Listing & 8 & $27 \%$ \\
\cline { 2 - 4 } & Translating & 3 & $30 \%$ \\
\cline { 2 - 4 } & Collocation grid & 5 & $10 \%$ \\
\cline { 2 - 4 } & Displaying it with images & 5 & $17 \%$ \\
\cline { 2 - 4 } & Comparing it with a synonym word & 30 & $100 \%$ \\
\hline \multicolumn{1}{c}{ Total } & & &
\end{tabular}

Table 12 showes that most of the answered were that techniques they use in learning collocations were translating 9 of $30(30 \%), 8$ of $30(27 \%)$ said listing, 8 of $30(27 \%)$ said that they displayed it with images, 3 of $30(10 \%)$ said that they used collocation grids and 5 of $30(5 \%)$ said that they compared the individual word of collocation to its synonym.

Table 13. Language Skills

\begin{tabular}{clccc}
\hline \multirow{2}{*}{ Item } & \multicolumn{2}{c}{ Options } & \multicolumn{2}{c}{ Teachers } \\
\cline { 2 - 4 } & & $f$ & $\%$ \\
\hline \multirow{3}{*}{$\begin{array}{l}\text { Which language skill(s) would be the most } \\
\text { effective in learning collocations? }\end{array}$} & Reading & 12 & $40 \%$ \\
\cline { 2 - 5 } & Listening & 5 & $17 \%$ \\
\cline { 2 - 4 } & Speaking & 4 & $13 \%$ \\
\cline { 2 - 4 } & Writing & 9 & $30 \%$ \\
\hline Total & & 30 & $100 \%$ \\
\hline
\end{tabular}

Table 13 showes that 12 of 30 (40\%) said that language skill(s) would be the most effective in learning collocations was reading, 9 of $30(30 \%)$ said that language skill(s) would be the most effective in learning collocations was writing, 5 of $30(17 \%)$ said that language skill(s) would be the most effective in learning collocations was listening and 4 of 30 (13\%) said that language skill(s) would be the most effective in learning collocations was Speaking.

Table 14. Collocation Errors

\begin{tabular}{|c|c|c|c|}
\hline \multirow{2}{*}{ Item } & \multirow{2}{*}{ Options } & \multicolumn{2}{|c|}{ Teachers } \\
\hline & & $f$ & $\%$ \\
\hline \multirow{2}{*}{$\begin{array}{l}\text { What are the causes } \\
\text { for EFL learners' } \\
\text { collocational errors? }\end{array}$} & $\begin{array}{l}\text { Students have the habit of learning } \\
\text { new vocabulary through individual } \\
\text { words }\end{array}$ & 6 & $20 \%$ \\
\hline & No rule for collocations & 9 & $30 \%$ \\
\hline
\end{tabular}




\begin{tabular}{llcc} 
& There is interference from Indonesian & 13 & $43 \%$ \\
\cline { 2 - 4 } & The knowledge of collocation is vast & 2 & $7 \%$ \\
\cline { 2 - 4 } & $\begin{array}{l}\text { The concept of collocation is not } \\
\text { clearly explained }\end{array}$ & 2 & \\
\cline { 2 - 4 } & Students awareness of collocation & 4 & $13 \%$ \\
\hline Total & 30 & $100 \%$ \\
\hline
\end{tabular}

Table 14 showes that EFL learners of pre-service teaching program answered that the errors on collocation rooted from the interference from Indonesian (43\%), 9 out of $30(30 \%)$ said that there is no rule for collocations, 6 out of $30(20 \%)$ said that the habit of learning new vocabulary through individual words, 4 out of $30(13 \%)$ said that they lack of awareness of collocation $(n=4), 2$ out of $30(7 \%)$ said that he concept of collocation is not clearly explained.

Table 15. Supplementary exercises to improve collocational knowledge

\begin{tabular}{clrr}
\hline \multirow{2}{*}{ Item } & \multicolumn{2}{c}{ Options } & \multicolumn{2}{c}{ Teachers } \\
\cline { 2 - 4 } & & $f$ & $\%$ \\
\hline \multirow{4}{*}{$\begin{array}{l}\text { What is the most helpful } \\
\text { exercises to increase } \\
\text { collocations? }\end{array}$} & Multiple choice & 8 & $27 \%$ \\
\cline { 2 - 4 } & Matching & 7 & $23 \%$ \\
\cline { 2 - 4 } & Gap filling & 4 & $13 \%$ \\
\cline { 2 - 4 } & Correcting mistakes & 2 & $17 \%$ \\
\cline { 2 - 4 } & Finding synonyms and antonyms & 4 & $13 \%$ \\
\cline { 2 - 4 } & Translating & 30 & $100 \%$ \\
\hline \multicolumn{1}{c}{ Total } & & & \\
\hline
\end{tabular}

Table 15 shows that 8 out of $30(27 \%)$ EFL learners of pre-service teaching program were multiple choice, 7 out of $30(23 \%)$ EFL learners of preservice teaching program were matching, 5 out of $30(17 \%)$ EFL learners of preservice teaching program were ccorrecting mistakes, 4 out of $30(13 \%)$ EFL learners of pre-service teaching program were gap filling, 4 out of 30 (13\%) EFL learners of pre-service teaching program were translating exercises, 2 out of 30 (7\%) EFL learners of pre-service teaching program were finding synonyms and antonyms.

\section{Discussion}

The findings revealed that the EFL learners of pre-service teaching programs' ability when using Preposition + noun pattern was at the highest level $(43 \%)$. On the other hand, the patterns Verb + noun, Adjective + preposition and Noun + to infinitive were used correctly at the lowest level $(20 \%$ all of them). This score indicator came up because EFL learners of pre-service teaching programs 'used these patterns in multiple occasions, where sometimes they succeed and sometimes they do not. However, the research demonstrated that EFL learners of pre-service teaching programs 'produced collocation errors because in the process of deciding which collocates should be utilized; it is probably that they recurred to the approximation of L1 and FL 
whether morphological, semantically or phonological. Examples are hard coffee (instead of strong coffee), strong rain (instead of heavy rain). Additionally, the results disclosed that the EFL learners of pre-service teaching programs 'applied L1 literal translation when deciding to choose the correct word, thus L1 affected directly L2 performance. These findings were similar to those described by Setiarini (2018), Maryani (2012) and Rao (2018).

In the other hand, the finding in questionnaires revealed that the role of collocation in teaching vocabulary is very important. It is obvious that teachers have to know the role of collocation is very important in teaching or learning vocabulary because collocations are a significant part of L2 vocabulary appropriate development. Lewis and Conzett (2000) stated that teaching collocation; teachers have to focus on chunks and their applications. EFL learners of pre-service teaching program chose to learn all collocations in the course book. Obviously, they have to choose what collocation are the best to be learnt. Be clear about independent collocations or idioms that are too problematic and boost them to get the meaning of a new word from the context. They should have been focused on difficult words and the examples provided in the dictionary. The most suitable level to teach collocations indicated that it can be taught at around elementary. They agreed that EFL teachers has to encourage students in reading and listening skills in identify collocations while writing and speaking skills are used to practice collocations. The most common reason for providing collocations was because their habitually learn individual words. They said that the best techniques in learning and teaching collocation is through translating and EFL teachers are responsible to select the appropriate ones for their students. Increasing the students' consciousness of collocations is the main goal. They claimed that reading would be the most effective language skill in teaching collocations and the most helpful exercises to increase collocations is through multiple choise. They also stated that the interference from Indonesian as the highest causes for their collocation errors. This finding is agreed with previous finding mentioned in the background of the study. Teachers must break down the collocation as individual words because they are need to be specified. They also need to know how the new apprehended terms work.

\section{Conclusion}

This research revealed collocational errors of Indonesian EFL learners of pre-service teaching program and their attitude toward teaching materials, learning methods, and teaching techniques.. The difference performance of the 30 Indonesian EFL learners of pre-service teaching program could be due to the huge numbers of English collocations. They might have known somel collocations and unconsciously making collocational errors are considered natural in specific way. They did not only poor in collocations, but also their lacking of awareness has not been raised yet to be sensitive about collocations. Since they have been learning collocations from their EFL teachers, making collocational errors could not justifiable. The student errors could be described as following: (1) they have intralingual problems; instead of doing homework, they probably incorrectly use making homework; (2) they may use negative transfer from their first language; some of them tend to say close the light 
instead of turn off the light; (3) they may over generalize directions for collocations that do not function for all of them. For example, in using take off your coat, they thought they could use the opposite is take on your coat; (4) they learn words individually, the chances of using appropriately collocations, decreases; (5) they can transfer literally an idiom. For example, hanging out does not make sense for students because it does not exist in Indonesian; (6) when they read, they probably do not recognize meaningfully collocations, which would block the understanding of the text; (7) they have problems in arrange correct collocations due to several problems. Teaching collocations to all English level is the solution. Therefore, their awareness of collocation should be raised by their EFL teachers. This study also revealed their attitudes on teaching collocations, techniques of collocation teaching, practicing frequency, teacher's view about students' collocation errors, and teaching techniques.

\section{Suggestion}

The knowledge of collocations is vital to master language acquisition therefore it is essential to make students conscious of collocations. But along the way, the interference of mother tongue stands as a major problem for the students. In order to cope the problem, teachers must know how to deal with it. There are some suggestions offered by the researcher in 3 (three) areas, they are: teaches role in establishing classroom activities and teaching collocations, encouraging students aware of collocations and establishing classroom activities.

There are some roles of teachers in teaching collocation. Laufer and Waldman (2011) proposed four steps to cope the problems in teaching of collocations. Firstly, make students comprehend the concept of collocations. Secondly, light up the collocations awareness using materials for specific collocations. Thirdly, show them how to detect collocations in activities and tasks. Lastly, evaluate and give feedback on their work.

Teachers have to encourage students aware of collocations. The researcher agreed with Bouma (2009) who stated the following strategies: (1) teaching the definition of collocations; (2) using extra exercises in the classroom activities; (3) using a meaningful context to teach collocations; (4) asking questions to the students to reinforce collocations; (5) choosing several vocabulary textbooks; (6) encouraging students to identify collocations when reading and also, asking them to make a list of collocation; (7) using the topic that students are able to use collocations in their writing; (8) making them use a collocation dictionary.

\section{Acknowledgement}

The researcher wishes to express her appreciation to the institution and some individuals for their constributions. Special thanks are addressed to the Institute for Research, Development and Community Service (Lembaga Penelitian Pengembangan dan Pengabdian kepada Masyarakt) IKIP Muhammadiyah Maumere as an activity funder or donor. The researchers are fully aware that without them this work would not have been possible. In this best opportunity, the researcher would like to express deepest gratitude to parties who helped carry out activities. 


\section{References}

Ahangari, S., \& Zununi V. (2013). A Comparative Study of the Use of Collocation in Iranian High School Textbooks and American English. File Books

Al-Sofi, M. \& Baker. (2014). Qur'anic Collocations: A Problem In Translation Quranica. International Journal of Quranic Research, 6 (2).

Alsullayi. (2015). The Use of Grammatical Collocations by Advanced Saudi EFL Learners in the UK and KSA. International Journal of English Linguistics; Vol. 5, No. 1

Bahardouzt \& Moeini (2012). Lexical and Grammatical Collocations in Writing Production of EFL Learners. The Journal of Applied Linguistics Vol. 5, Issue 1

Benson, M., Benson, E., \& Ilson, R. (1997). The BBI dictionary of English wordcombinations. Amsterdam: John Benjamins.

Bouma, G. (2009). Normalized (pointwise) mutual information in collocation extraction. Proceedings of GSCL, 31-40.

Dweik, B., \& Shakra, M. (2011). Problems in Translating Collocations in Religious Texts from Arabic into English The Linguistics Journal. 5 (1).

Fadlilah. (2016). Students' Grammatical Collocation Errors and its' Implication in Teaching Writing Walisongo State Islamic University Semarang IJET | Volume 5, Issue 2

Farrokh. (2012). Raising Awareness of Collocation in ESL/EFL. Classrooms Journal of Studies in Education. 2 (3) http://dx.doi.org/10.5296/jse.v2i3

Laufer, B., \& Waldman, T. (2011). Verb-Noun Collocations in Second Language Writing: A Corpus Analysis of Learners' English. Language Learning, 61(2), 647-672.

Lewis, M., Conzett, J. (2000). Teaching collocation: Further developments in the lexical approach. Hove: Language Teaching Publications

Malenica \& Mustapić. (2015). Acquisition of English Collocations through Productive Skills-Analysis of Translation Errors International Journal of English Linguistics; 5, (4);

Maryani. (2012). What English Collocations to Teach First to Indonesian Preschool Children? A mini-corpus based research of indonesian children's storybooks, Indonesian Journal of Applied Linguistics, 1 (2)

McCarthy, M. (2005). English collocations in use. Cambridge: Cambridge University Press.

Mutlu \& Kaşlioğlu (2016). Turkish EFL Teachers' and Learners' Perceptions of Collocations Sakarya University Journal of Education, 6 (3)

Owu-Ewie \& Williams 2017; Grammatical and Lexical Errors in Students' English Composition Writing: The Case of Three Senior High Schools 
(SHS) in the Central Region of Ghana Sino-US English Teaching, August 2017, Vol. 14, No. 8, 463-482 doi:10.17265/1539-8072/2017.08.001

Shamsudin, Sadoughvanini \& Zaid (2013). Iranian EFL learners' Collocational errors in speaking skill. Akdeniz Language Studies Conference 2012 Procedia - Social and Behavioral Sciences 70, 1295 - 1302

Setiarini, P. (2018). Collocation Errors by Indonesian EFL Learners: Types of Errors, Translation Techniques, and Causes of Errors

Oxford collocations dictionary $2^{\text {nd }}$ edition. (2009). Oxford: Oxford University Press.

Qader. (2018). The Role of Teaching Lexical Collocations in Raising EFL Learners' Speaking Fluency Journal of Literature, Languages and Linguistics Vol.46, 2018

Rao. (2018). The Importance of Collocations in Teaching of Vocabulary. Journal of Research Scholars and Professionals of English Language Teaching, $7(2)$

Rahman, F. (2018). The Constraints of Foreign Learners in Reading English Literary Works: A Case Study at Hasanuddin University. Journal of Arts and Humanities, 7(2), 01-12.

Rudzka, P., \& Ostyn. (1981). More Words You Need. London: Macmillan

Torabian, M., \& Subakir. (2014). Lexical collocational knowledge of Iranian undergraduate learners: implications for receptive \& productive performance. 14th International Language, Literature and Stylistics Symposium. Procedia - Social and Behavioral Sciences 158

Yazdandoost, S., \& Kafipour. (2014); The Relationship Among Collocation Knowledge And Listening, Speaking, Reading And Writing Proficiency Of Iranian EFL Learners. Journal of International Scientific Publications Language, Individual \& Society. Volume 8 